\title{
Analisis Kemampuan Ruang Terbuka Hijau Dalam Menyerap Sisa Emisi Karbon (Studi Kasus: Hutan Kota Muhammad Sabki Kota Jambi)
}

\author{
Muhammad Fajar ${ }^{1}$, G.M. Saragih ${ }^{2 *}$, dan Soni Pratomo ${ }^{3}$ \\ ${ }^{1,2}$ Program Studi Teknik Lingkungan Universitas Batanghari \\ Jalan Slamet Riyadi, Broni, Kota Jambi \\ ${ }^{3}$ Bappeda Provinsi Jambi \\ Jalan Rm. Noor Admadibrata No. 1, Telanaipura, Kota Jambi \\ *correspondence email: saragihguntar@gmail.com
}

\begin{abstract}
Muhammad Sabki City Forest is one of the urban forests that is used as Green Open Space in Jambi City, one of the functions of urban forests is absorbing $\mathrm{CO}_{2}$ gas emissions, the analysis carried out in the forest city of Muhammad Sabki in Jambi is to find out how much CO emissions remaining by determining tree canopy / cover points consisting of 3 measurement locations, measurements carried out in the morning,

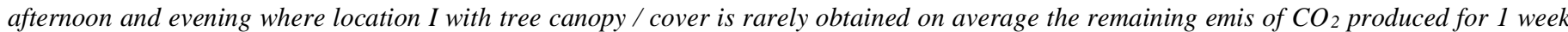
at in the morning at 420.762 ppm, during the day 403.057 ppm, and in the afternoon at 409.038 ppm, while at location II with density / medium tree cover, in the morning it was 420.610 ppm, during the day 401.762 ppm, and in the afternoon 409,210 ppm, then at the location of point III in the morning it was 420,429 ppm, during the day 402,981 ppm and in the afternoon 414,638 ppm. Where is the average residual CO emissions produced? an annual 0,150 (tons / year) this shows that it is still in accordance with the criteria for quality standards for air quality so that the city of Muhammad Sabki Jambi City still has good quality in absorbing residual $\mathrm{CO}_{2}$ emissions generated from activities or activities of humans and other living things.
\end{abstract}

Keywords: Urban Forest, Tree Head / Cover, Remaining $\mathrm{CO}_{2}$ Emissions.

\section{Pendahuluan}

Bertambahnya jumlah penduduk tentunya mengakibatkan kebutuhan lahan terbangun di perkotaan terus meningkat sehingga fungsi ruang dikawasan perkotaan menjadi semakin beragam seperti pusat pemerintahan, pendidikan, perdagangan dan jasa (Velayati.L.H dkk, 2012). Menurut IPCC (2007), aktivitas manusia merupakan penyumbang terbesar emisi rumah kaca terutama dari konsumsi energi yakni sebesar $26 \%$.

Ruang Terbuka Hijau (RTH) memiliki fungsi ekologis, salah satu fungsi yaitu sebagai areal resapan air, penghasil oksigen, peredam kebisingan, fiter dari partikel padat yang mencemari udara kota, serta sebagai penjerap $\mathrm{CO} 2$ (Velayati.L.H dkk, 2012).

Permasalahan lingkungan di Kota Jambi salah satunya ditimbulkan akibat terjadinya peningkatan kawasan untuk permukiman dan meningkatnya jumlah penduduk yang berdampak pada daya tampung lingkungan, sehingga menyebabkan jumlah $\mathrm{CO} 2$ yang dihasilkan meningkat. Kemampuan penyerapan pada tanaman dan pohon merupakan salah satu cara untuk mengurangi emisi CO2 tersebut.

Salah satu tipe Ruang Terbuka Hijau (RTH) adalah Hutan Kota. Berdasarkan Undang-undang Peraturan Pemerintah Nomor 41 Tahun 1999 pasal 9 tentang Hutan Kota, menyebutkan bahwa Hutan Kota adalah suatu hamparan lahan yang bertumbuhan pohon-pohon yang kompak dan rapat di dalam wilayah perkotaan baik pada tanah Negara maupun tanah hak, yang ditetapkan sebagai hutan kota oleh pejabat yang berwenang.

Kota Jambi memiliki Hutan Kota Muhammad Sabki. Hutan kota Muhammad Sabki terletak di Kecamatan Kota Baru, Kota Jambi dengan luasan 10,7 Ha (Dinas Lingkungan Hidup Kota Jambi, 2018), kemampuan Hutan Kota
Muhammad Sabki dalam menyerap emisi CO2 sebagai penunjang RTH, dengan menghitung sisa emisi yang dihasilkan dari aktivitas penduduk sekitar, dan menganalisis kemampuan vegetasi dalam menyerap emisi CO2.

Berdasarkan uraian diatas penelitian ini bertujuan untuk (1) Menghitung sisa emisi CO2 yang dapat diserap oleh vegetasi Hutan Kota Muhammad Sabki; (2) Membandingkan sisa emisi CO2 pada variasi tajuk pohon yang ada dikawasan hutan kota Muhammad Sabki dan menganalisis kemampuan vegetasi dalam penyerapan $\mathrm{CO} 2$.

\section{Metode Penelitian}

Penelitian ini dilaksanakan di Hutan Kota Muhammad Sabki, pada 3 titik lokasi yang berbeda tajuk/tutupan kerapatan pohon. Tiitik pertama pada penelitian berada pada tajuk/kerapatan pohon yang jarang berlokasi $\pm 100 \mathrm{~m}$ dari pintu masuk Hutan Kota Muhammad Sabki. Kemudian titik kedua pada penelitian ini berada pada tajuk/kerapatan pohon yang sedang berlokasi $\pm 250 \mathrm{~m}$ dari pintu masuk Hutan Kota Muhammad Sabki dan yang terakhir titik ketiga pada penelitian ini berada pada tajuk/kerapatan pohon yang sedang berlokasi \pm 500 m dari pintu masuk Hutan Kota Muhammad Sabki.

Pada penelitian ini, variabel terdiri atas variabel bebas dan veriabel terikat. Alat dan bahan yang digunakan yaitu alat CO2 meter, GPS (Global Positioning System), Laptop, Printer, bahan peta administrasi kecamatan Hutan Kota Muhammad Sabki.

Ada beberapa tahapan yang dilakukan pada penelitian, yaitu berupa persiapan alat dan bahan, pengumpulan data primer dan data sekunder, pengambilan sampel dan pengolahan data, inventarisasi vegetasi. Pada penelitian ini ada beberapa kegiatan yang dilakukan yaitu menentukan nilai $\mathrm{CO} 2$ 
menggunakan $\mathrm{CO} 2$ meter untuk mengetahui jumlah emisi $\mathrm{CO} 2$ yang ada saat ini. Kemudian menginventarisir jenis vegetasi di lokasi penelitian untuk melihat perbandingan emisi CO2 yang berbeda lokasi sampel.

Dari hasil pengambilan sampel CO2 di beberapa lokasi penelitian, akan diolah dengan teori kebutuhan ruang terbuka hijau untuk mengetahui kebutuhan ruang terbuka hijau saat ini.

\section{Hasil dan Pembahasan}

\subsection{Pengukuran $\mathrm{CO}_{2}$ selama satu minggu}

Pengukuran $\mathrm{CO} 2$ yang dilakukan dalam penelitian ini rata-rata dalam satu hari sebesar $416,859 \mathrm{ppm}$ pada hari pertama, 410,052 ppm pada hari kedua, dan seterusnya selama 7 hari sebesar 410,104 ppm, 408,104 ppm, 411,933 ppm, 411,919 ppm, 410,741 ppm. Hasil lengkapnya dapat dilihat pada gambar 1 .

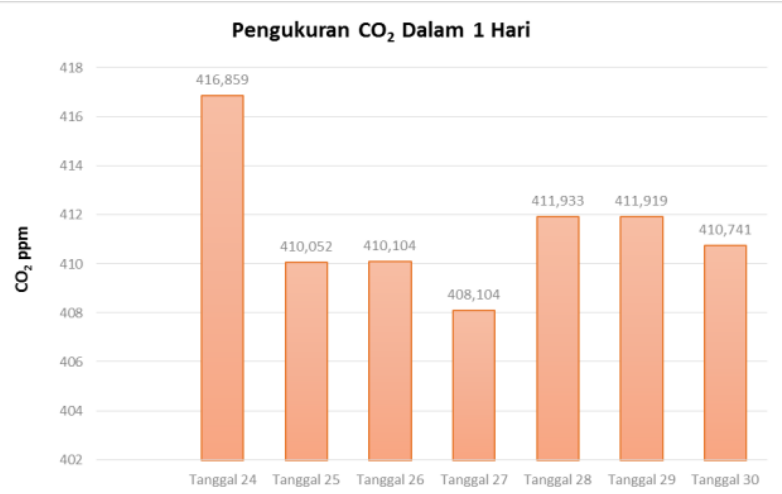

Gambar 1. Hasil Pengukuran $\mathrm{CO}_{2}$ Per-Hari Selama 1 Minggu

\subsection{Pengukuran $\mathrm{CO}_{2}$ pagi hari}

Pengukuran CO2 pada lokasi I, lokasi II, dan lokasi III menujukan tutupan pohon yang jarang dan sedang, dengan melakukan pengambilan titik sample selama 15 menit di waktu pagi selama satu minggu dengan jumlah pengunjung rata-rata sebesar 20-50 orang perharinya sehingga dalam pengukuran menunjukan daya serapan pohon terhadap sisa emisi $\mathrm{CO} 2$ dapat dilihat pada gambar 2.

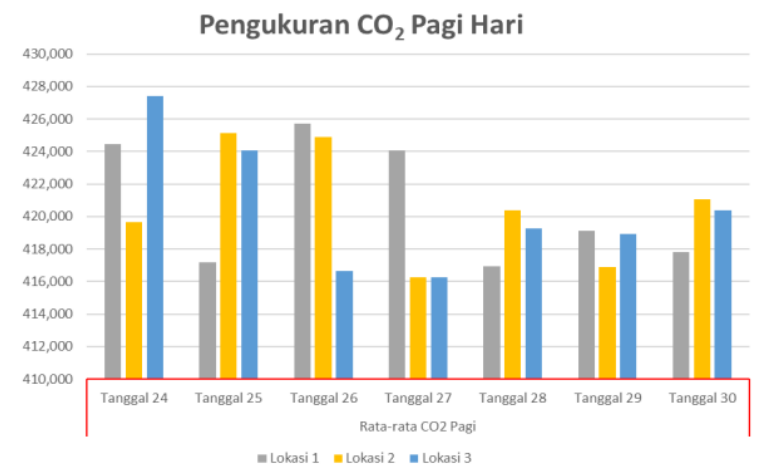

Gambar 2. Hasil Pengukuran $\mathrm{CO}_{2}$ Pada Pagi Hari Selama 1 Minggu

Pengukuran yang dilakukan selama satu minggu di pagi hari pada titik lokasi I,II dan III menujukan angka rata-rata CO2 yang dihasilkan sebesar 420,762 ppm pada lokasi I, 420,610 ppm pada lokasi II, dan 420,429 ppm pada lokasi titik
III. Hasil paling besar terdapat pada lokasi I dengan tajuk/kerapatan pohon jarang dan yang paling kecil terjadi pada lokasi III dimana tajuk/kerapatan tutupan pohon rapat hal ini dikarenakan pengaruh pengunjung lebih banyak melakukan aktivitas pada lokasi I, II, dan III seperti olah raga, tamasya dan sebagainya.

\subsection{Pengukuran $\mathrm{CO}_{2}$ siang hari}

Pengukuran pada siang hari dilakukan antara jam 13.00-14.00 wib, dengan rentang waktu pengambian sampel selama 15 menit di tiga titik lokasi berbeda, rata-rata $\mathrm{CO} 2$ yang dihasilkan selama 1 minggu, yaitu pada lokasi I menunjukan penurunan CO2 sebesar 403,057 ppm dibandingkan dengan pengambilan sample pada pagi hari yaitu sebesar 420,762 ppm, untuk lokasi II CO2 yang diukur menunjukan angka penurunan sebesar 401,762 ppm sedangkan pada pagi hari sebesar $420,610 \mathrm{ppm}$, dan pada lokasi III pengukuran CO2 meningkat sebesar 402,981 ppm dan dipagi hari pada lokasi III menunjukan angka 420,429 ppm terlihat pada siang hari hasil pengukuran rata-rata $\mathrm{CO} 2$ terlihat jauh lebih rendah karena pada waktu siang matahari berperan dalam proses fotosintesis sehingga mempengaruhi rendahnya konsentrasi CO2 dibanding pagi hari. Pengukuran rata-rata $\mathrm{CO} 2$ dalam 1 minggu disajikan pada gambar 3.

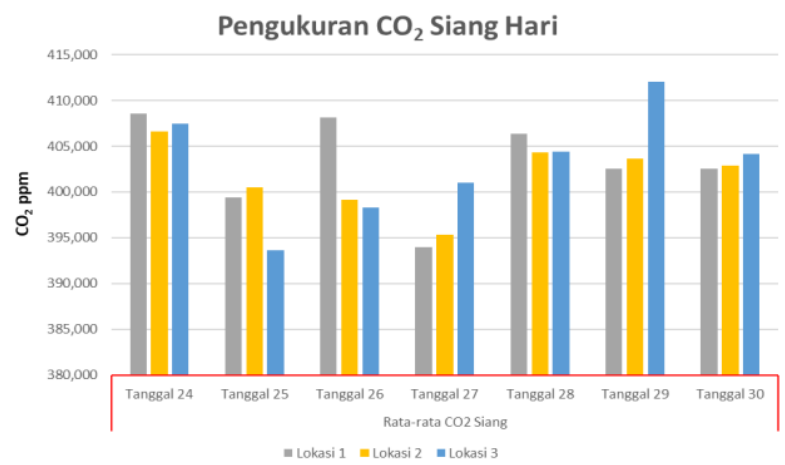

Gambar 3. Hasil Pengukuran $\mathrm{CO}_{2}$ Pada Siang Hari Selama 1 Minggu.

Hasil pengukuran menunjukan tingginya $\mathrm{CO} 2$ yang dihasilkan pada pagi hari dibandingkan dengan siang hari yang relatif lebih kecil, dari hasil pengamatan dilapangan, pengaruh tersebut akibat perubahan aktivitas manusia yang mulai berkurang pada siang hari yang biasanya waktu istirahat bagi pengunjung untuk meninggalkan lokasi dan mengurangi aktivitasnya.

\subsection{Pengukuran $\mathrm{CO}_{2}$ sore hari}

Pengukuran sore hari dilakukan antara jam 16.00-17.00 wib, waktu pengambian sampel untuk pengukuran $\mathrm{CO} 2$ selama 15 menit, rata-rata $\mathrm{CO} 2$ yang dihasilkan selama 1 minggu, yaitu pada lokasi I menunjukan peningkatan kenaikan CO2 sebesar 409,038 ppm dibandingkan dengan pengambilan sample siang hari sebesar 403,057 ppm, untuk lokasi II CO2 yang diukur menunjukan angka kenaikan sebesar 409,210 ppm sedangkan pada siang hari sebesar 401,762 ppm, kemudian pada lokasi III pengukuran $\mathrm{CO} 2$ meningkat sebesar 414,368 ppm pada sore hari, sedangkan pada siang hari 402,981 ppm. Hasil pengukuran rata-rata $\mathrm{CO} 2$ selama 1 minggu disajikan pada gambar 4 . 


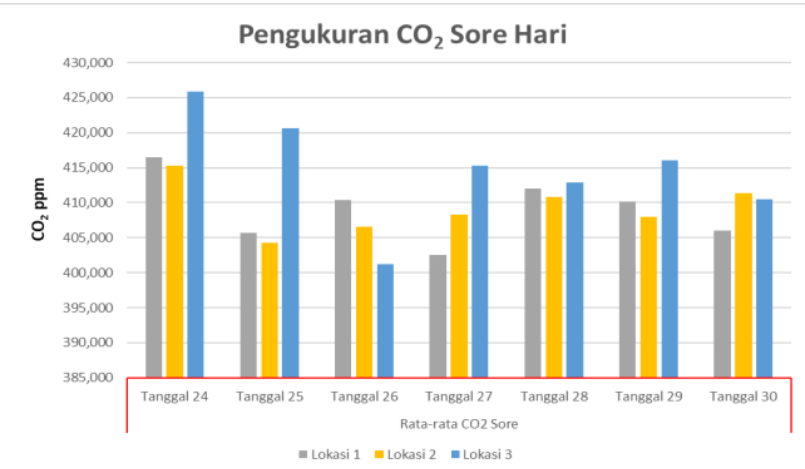

Gambar 4. Hasil Pengukuran $\mathrm{CO}_{2}$ Pada Sore Hari Selama 1 Minggu.

Aktivitas pengunjung yang dilakukan mulai meningkat pada sore hari, pengaruh umumnya yaitu pengunjung yang istirahat ataupun melakukan aktivitas setelah pulang dari kerja atau kegiatan lainya untuk melakukan olahraga, bersantai dan lain sebagainya, mengakibatkan peningkatan $\mathrm{CO} 2$ pada pengukuran sore hari.

\subsection{Sisa Emisi Karbon Pada Lokasi I}

Lokasi pengukuran yang dijadikan titik sampling yaitu tajuk/tutupan pohon yang jarang, tujuannya untuk mengetahui seberapa dominan penyerapan sisa emisi $\mathrm{CO} 2$ yang terjadi dengan tajuk/tutupan pohon yang dilakukan pada pagi, siang, dan sore selama 1 minggu pengukuran, data pengukuran disajikan pada gambar 5 .

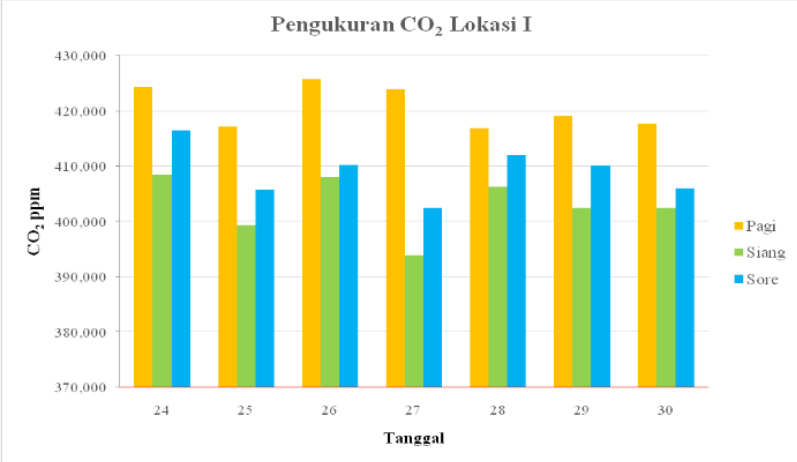

Gambar 5. Hasil Pengukuran $\mathrm{CO}_{2}$ di Lokasi I Selama 1 Minggu.

Grafik diatas menjelaskan hasil dari pengukuran pada tajuk/tutupan pohon dengan jarak atau kerenggangan yang jarang dan berlokasi $\pm 100 \mathrm{~m}$ dari pintu masuk, rata-rata hasil pengukuran selama satu minggu yaitu pada pagi hari dilokasi I menunjukan pengukuran $\mathrm{CO} 2$ sebesar 420,762 ppm, siang hari sebesar, 403,057 ppm, dan sore hari sebesar 409,038 ppm sedangkan dilokasi I pengukuran $\mathrm{CO} 2$ cukup tinggi, pengukuran dilakukan kembali pada siang hari menunjukan hasil pengukuran menurun yaitu sekitar 403,057 ppm, dan pengukuran sore hari mulai tinggi kembali sebesar 409,038 ppm, jenis pohon pada lokasi I terdiri dari petai, beringin, karet, medang labu.

\subsection{Sisa Emisi Karbon Pada Lokasi II}

Pengukuran CO2 pada lokasi II dilakukan pada tajuk/tutupan pohon sedang, dengan kondisi lingkungan banya wisatawan/pengunjung yang mulai melakukan aktivitas sehingga $\mathrm{CO} 2$ yang dihasilkan mulai, terlihat pada gambar 6 .

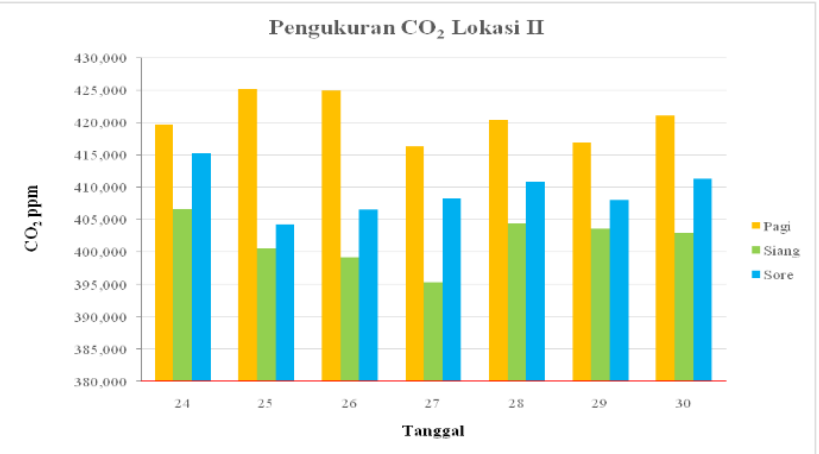

Gambar 6. Hasil Pengukuran $\mathrm{CO}_{2}$ di Lokasi II Selama 1 Minggu.

Rata-rata pengukuran $\mathrm{CO} 2$ yang dilakukan pada lokasi II selama 1 minggu, hasil data menunjukan pada pagi hari pengukuran $\mathrm{CO} 2$ sebesar 420,610 ppm, siang hari sebesar 401,762 ppm, dan pada sore hari yaitu 409,210 ppm, pengukuran pada tajuk/tutupan pohon yang jarang lebih tinggi pada pada pagi hari jika dibandingkan dengan tajuk/tutupan pohon yang sedang, pada lokasi II ini jenis pohon terdiri dari pohon gaharu, medang, bulian, jambu, karet, kelat dan jemutung. Hal ini karena aktivitas lebih banyak dilakukan pada lokasi II oleh pengunjung mengakibatkan peningkatan $\mathrm{CO} 2$ kembali pada sore hari, pengaruh lainnya $\mathrm{CO} 2$ yang berasal dari kendaraan bermotor, dan kondisi pohon tidak dapat menyerap lebih banyak lagi $\mathrm{CO} 2$, karena pohon banyak menyimpan karbohidrat sebagai cadangan makanan dari proses fotosintesis yang terjadi pada pagi dan siang hari.

\subsection{Sisa Emisi Karbon Pada Lokasi III}

Kondisi pada lokasi III sama dengan lokasi II dengan tajuk/tutupan pohon sedang, jenis pohon terdiri dari pohon gaharu, medang, bulian, jambu, karet, kelat dan jemutung. Dalam kemampuan penyerapan CO2, lokasi III cendrung lebih tinggi dibandingkan dengan lokasi I \& II, data pengukuran dapat dilihat pada gambar 7 .

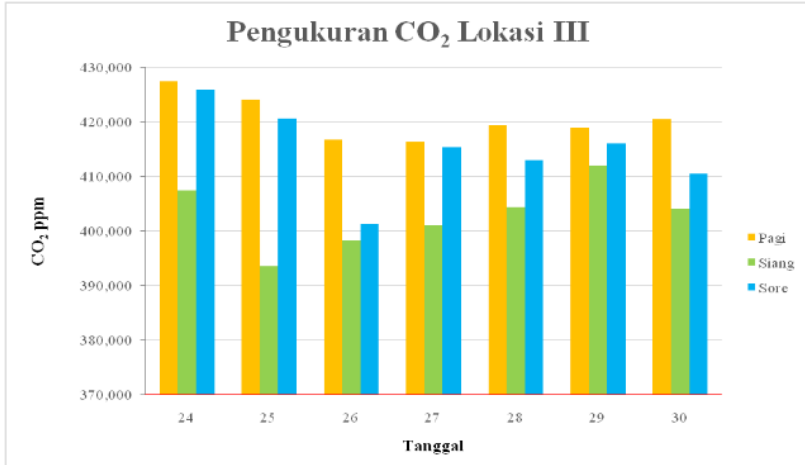

Gambar 7. Hasil Pengukuran $\mathrm{CO}_{2}$ di Lokasi III Selama 1 Minggu.

Pengukuran yang dilakukan selama satu minggu menunjukan hasil rata-rata $\mathrm{CO} 2$ pada lokasi III dengan data hasil pengukuran sebagai berikut, pada pagi hari CO2 yang diukur sebesar 420,429 ppm, siang hari 402,981 ppm, dan sore hari 414,638 ppm, pengukuran pada pagi hari lebih tinggi jika dibandingkan dengan lokasi I \& II, CO2 mulai mengalami penurunan pada siang hari akan tetapi masih tinggi jika dibandingkan dengan lokasi I \& II dikarenakan proses dari fotosintesis pada pohon yang telah banyak menyerap $\mathrm{CO} 2$ 
sebagai karbohidrat untuk cadangan makanan, sehingga pohon tidak dapat menyerap lebih banyak $\mathrm{CO} 2$, dan pada sore hari $\mathrm{CO} 2$ yang diukur mulai meningkat kembali kondisi dimana proses fotosintetis pada pohon mulai berkurang karena cahaya matahari tidak menyinari dedaunan, dan banyaknya aktivitas pada sore hari mengakibatkan meningkatnya $\mathrm{CO} 2$.

\subsection{Sisa Emisi CO2 Yang Di Hasilkan Selama Satu Tahun}

Dari pengukuran tajuk/tutupan pohon dengan kerapatan jarang dan sedang didapat sisa emisi $\mathrm{CO} 2$ yang dihasilkan dalam satu hari untuk pengamatan pertama dengan jumlah CO2 yaitu sebesar 416,859 ppm, sedangkan hari kedua menurun sekitar 410,052 ppm, dan dihari ketiga meningkat kembali dengan jumlah sebesar 410,104 ppm, dan menurun kembali pada hari keempat yaitu 408,104 ppm, kemudian meningkat pada hari kelima sebesar 411,933 ppm, dan menurun dihari keenam sebesar 411,919 ppm, dan untuk hari ketujuh menurun sebesar 410,741 ppm, sehingga rata-rata pertahun sisa emisi CO2 yang dihasilkan sebesar 150.156,4 ppm.

Hasil pengukuran uji sisa emisi CO2 yang dihasilkan sebagai berikut:

Sisa emisi $\mathrm{CO} 2=\mathrm{A}($ ton/tahun $)-\mathrm{B}($ ton/tahun $)$

Keterangan :

$\mathrm{A}=$ Total Emisi $\mathrm{CO} 2$

$\mathrm{B}=$ Total Daya Serap CO2

Kemudian, luasan RTH yang dibutuhkan dicari dengan menggunakan persamaan berikut :

Kebutuhan $\mathrm{RTH}=\frac{\text { Sisa Emisi } \mathrm{CO}_{2}}{\text { Kemampuan pohon dalam menyerap } \mathrm{CO}_{2}}$

Sehingga :

Klasifikasi Vegetasi

Luas Pohon $=10,6 \mathrm{Ha}$

Rumput $\quad=0,4 \mathrm{Ha}$

Klasifikasi Ketentuan Daya Serap CO2

Pohon $=569,07$

Rumput $\quad=12$

Hasil ukur CO2 rata-rata perhari yang didapat dikali dengan 365 hari $(1$ tahun $)=150.156,4$ ppm dikonversikan ke ton/tahun didapatkan 0,150 (ton/tahun):

Daya serap pohon terhadap CO2 569,07 dikali 10,06 $\mathrm{Ha}=$ 5.724,8 (ton/tahun);

Daya serap rumput terhadap CO2 0,4 Ha dikali $12=4,8$ (ton/tahun);

Daya serap pohon ditambah daya serap rumput $5.724,8+4,8$

$=5.729,6$ (ton/tahun $)$

Persamaannya sebagai berikut :

Sisa emisi CO2 = 0,150 ( $\left.\frac{\text { ton }}{\text { tahun }}\right)-5729,6$ (ton/tahun)

Sisa emisi CO2 $=-5.729,45$ ton/tahun

Kebutuhan RTH $=\frac{-5729,4 \text { ton } / \text { tahun }}{569,07 \text { ton } / \text { tahun } / \text { ha }}$

Kebutuhan RTH $=-10,06$ ha

\subsection{Respon Pohon Terhadap Meningkatnya $\mathrm{CO} 2$}

Kelebihan $\mathrm{CO} 2$ yang dihasilkan mengakibatkan pohon mengalami penipisan pada dinding bundle seath cell, apabila konsentrasi $\mathrm{CO} 2$ nya tinggi. Hal ini disebabkan karena penurunan jumlah suberin pada dinding sel dan menyebabkan terjadinya peningkatan konsentrasi $\mathrm{CO} 2$, pengaruh lainnya dari proses fotosintesis pada pohon dimana penurunan konduktansi pada stomata pada daun mengakibakan perubahan konsentrasi $\mathrm{CO} 2$ sehingga $\mathrm{CO} 2$ yang dihasilkan menjadi lebih atau meningkat, penelitian yang dilakukan terhadap tajuk/tutupan pohon yang jarang cendrung memiliki cabang dan daun pohon yang kecil sehingga penyerapan $\mathrm{CO} 2$ dapat diantisipasi oleh pohon cukup baik, akan tetapi dengan tajuk/tutupan pohon yang sedang memiliki faktor fisiologis pada pohon seperti daun lebih tebal, sehingga merubah rasio luas permukaannya dan mengubah aktivitas pohon seperti fotosintesis, pertukaran gas, pendinginan evaporatif dan penyimpanan gula pada batang, akibatnya menurunkan kualitas udara ambien dalam lingkungan dan perubahan pada iklim bumi.

\section{Kesimpulan}

Berdasarkan analisis dan pembahasan yang telah dilakukan maka dapat diambil beberapa kesimpulan berkenaan dengan tujuan yang diharapkan dari penelitian ini, yaitu: Hutan Kota Muhammad Sabki, Kota Jambi Terdiri dari 3 titik lokasi pengambilan sample, Hasil ukur sisa emisi CO2 yang dihasilkan terdiri dari kerapatan tajuk/tutupan pohon jarang dan sedang, di tiga titik lokasi rata-rata tertinggi pada pagi hari yaitu pada titik lokasi I sebesar 420,762 ppm, dan pada siang hari sebesar 403,057 ppm, kemudian pada sore hari yang terbesar pada titik lokasi III yaitu sebesar 414,638 ppm, sehingga lokasi dengan jumlah sisa emisi CO2 terbesar dihasilkan pada titik tajuk tutupan pohon yang jarang yaitu di titik lokasi I, menurut analisis lampiran I PERMEN LH No.12 Tahun 2010 tentang Pedoman Teknis Penetapan Baku Mutu Udara Ambien Daerah, hutan kota Muhammad Sabki, Kota Jambi menghasilkan sisa emisi CO2 per-tahunnya yaitu sebesar 0,150 (ton/tahun), untuk daya serap pohon terhadap $\mathrm{CO} 2$ yaitu sebesar $5.724,8$.

\section{Daftar Pustaka}

Undang-undang Peraturan Pemerintah Nomor 41 Tahun 1999 pasal 9.

Velayati, L.H, dkk. (2012). Analisis Kebutuhan Ruang Terbuka Hijau (RTH) Berdasarakan Serapan Gas CO2 Di Kota Pontianak, 4-6. 